\title{
Vibrio neptunius sp. nov., Vibrio brasiliensis sp. nov. and Vibrio xuii sp. nov., isolated from the marine aquaculture environment (bivalves, fish, rotifers and shrimps)
}

\author{
F. L. Thompson, ${ }^{1,2}$ Y. Li, ${ }^{3}$ B. Gomez-Gil,, ${ }^{4}$ C. C. Thompson, ${ }^{1}$ B. Hoste, ${ }^{2}$ \\ K. Vandemeulebroecke, ${ }^{2}$ G. S. Rupp, ${ }^{5}$ A. Pereira, ${ }^{5}$ M. M. De Bem, ${ }^{5}$ \\ P. Sorgeloos ${ }^{6}$ and J. Swings ${ }^{1,2}$ \\ 1,2 Laboratory for Microbiology ${ }^{1}$ and BCCM ${ }^{\mathrm{TM}} / \mathrm{LMG}$ Bacteria Collection${ }^{2}$, Ghent University, \\ K. L. Ledeganckstraat 35, Ghent 9000, Belgium \\ ${ }^{3}$ College of Marine Life Sciences, Ocean University of Oingdao, 5 Yushan Road, Oingdao, \\ 266003, China \\ ${ }^{4}$ CIAD/Mazatlán Unit for Aquaculture, AP. 711, Mazatlán, Sinaloa, Mexico 82000 \\ ${ }^{5}$ Laboratory for Culture of Marine Molluscs, Federal University of Santa Catarina, Department \\ of Aquaculture, Florianópolis, Brazil \\ ${ }^{6}$ Laboratory of Aquaculture and Artemia Reference Center, Ghent University, Rozier 44, Ghent \\ 9000, Belgium
}

Correspondence

F. L. Thompson

Fabiano.Thompson@rug.ac.be
The fluorescent amplified fragment length polymorphism (FAFLP) groups A5 (21 isolates), A8 (6 isolates) and A23 (3 isolates) distinguished in an earlier paper (Thompson et al., Syst Appl Microbiol $24,520-538,2001)$ were examined in more depth. These three groups were phylogenetically related to Vibrio tubiashii, but DNA-DNA hybridization experiments proved that the three AFLP groups are in fact novel species. Chemotaxonomic and phenotypic analyses further revealed several differences among the $\mathbf{3 0}$ isolates and known Vibrio species. It is proposed to accommodate these isolates in three novel species, namely Vibrio neptunius (type strain LMG $20536^{\top}$; EMBL accession no. AJ316171; G $+C$ content of the type strain $46 \cdot 0$ mol\%), Vibrio brasiliensis (type strain LMG 20546 ${ }^{\top}$; EMBL accession no. AJ316172; G $+\mathrm{C}$ content of the type strain $45.9 \mathrm{~mol} \%$ ) and Vibrio xuii (type strain LMG 21346 ${ }^{\top}$; EMBL accession no. AJ316181; G $+\mathrm{C}$ content of the type strain $46 \cdot 6$ mol\%). These species can be differentiated on the basis of phenotypic features, including fatty acid composition (particularly $14: 0$ iso, $14: 0$ iso $3-\mathrm{OH}, 16: 0$ iso, $16: 0,17: 0$ and $17: 1 \omega 8 c$ ), enzyme activities and utilization and fermentation of various carbon sources.

\section{INTRODUCTION}

It is well recognized that bacteria play a pivotal role in the cycling of dissolved and particulate organic matter in aquatic ecosystems (Sherr \& Sherr, 2000). There has been increasing evidence that bacteria also fuel food webs in marine aquaculture systems and influence the health of cultured marine organisms (Hansen \& Olafsen, 1999;
Thompson et al., 2002a). Vibrios are highly abundant in aquatic ecosystems, particularly in eutrophic environments,

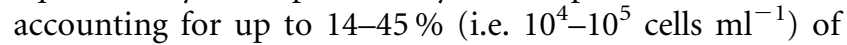
the culturable microbiota (Eilers et al., 2000; Suantika et al., 2001). Moreover, vibrios are present in large numbers in a successful recirculating system for rotifers (Suantika et al., 2001) and are also part of the normal flora of penaeid

Published online ahead of print on 12 July 2002 as DOI 10.1099/ijs.0.02447-0.

Abbreviations: FAFLP, fluorescent amplified fragment length polymorphism; FAME, fatty acid methyl ester; TCBS, thiosulphate/citrate/bile salts/ sucrose; TSA, tryptone soy agar.

The GenBank/EMBL/DDBJ accession numbers for the 16 S rDNA sequences of LMG strains $20536^{\top}, 20546^{\top}, 21346^{\top}, 20613,20010$ and 21347 are respectively AJ316171, AJ316172, AJ316181 and AJ490150-AJ490152.

Additional phenotypic features of the three novel species are listed as supplementary material in IJSEM Online (http://ijs.sgmjournals.org/). 
shrimps (Gomez-Gil et al., 1998). Certain Vibrio strains stimulate reproduction and ameliorate growth rates of molluscs and rotifers and protect Artemia against bacterial infections, whereas other Vibrio strains constitute serious pathogens or potential pathogens for the same organisms (Riquelme et al., 2001; Verschuere et al., 2000).

Recently, we surveyed the genomic diversity of 506 strains of the Vibrionaceae by means of the fluorescent amplified fragment length polymorphism (FAFLP) technique (Thompson et al., 2001). Many isolates from the aquaculture environment possess genomes that differ from currently known Vibrio species and are thus potentially novel species. In the present study, we describe additional genomic and phenotypic characteristics of a subset of 30 isolates distributed in the FAFLP groups A5, A8 and A23. FAFLP cluster A5 represented mainly the dominant culturable bacterial microflora of a recirculating system for rotifers (Suantika et al., 2001). Group A8 was abundant in cultures of larvae of the bivalve Nodipecten nodosus at Florianópolis, in southern Brazil, whereas group A23 was found to be ubiquitous and in association with cultured shrimps in China and Ecuador and in cultures of N. nodosus larvae in Brazil.

\section{METHODS}

Bacterial strains, growth conditions and DNA isolation. Strains used in this study are described in Table 1. Strains were grown aerobically on tryptone soy agar (TSA; Oxoid) supplemented with $2 \%(\mathrm{w} / \mathrm{v}) \mathrm{NaCl}$ for $24 \mathrm{~h}$ at $28{ }^{\circ} \mathrm{C}$. DNA was extracted following the method described by Pitcher et al. (1989). All strains included in this study have been deposited in the BCCM/LMG Bacteria Collection at Ghent University and in the CAIM collection of the Centre for Research on Nutrition and Development (CIAD) in Mazatlán, Mexico.

Genotypic analyses. Selective amplification of restriction fragments (FAFLP) and sequencing of almost complete 16S rDNA sequences were accomplished essentially as described previously (Thompson et al., 2001). Alignment of the 16S rDNA sequences, distance estimations (Jukes \& Cantor, 1969), clustering by the neighbour-joining (Saitou \& Nei, 1987), maximum-likelihood and maximum-parsimony methods and analysis of the stability of clusters (bootstrap analysis with 1000 replicates) were performed with the software BioNumerics 2.5 (Applied Maths). DNA-DNA hybridization experiments using photobiotin-labelled DNAs were run under stringent conditions $\left(39^{\circ} \mathrm{C}\right)$ following the method of Willems et al. (2001). The G $+\mathrm{C}$ content of DNA was determined by HPLC (Mesbah et al., 1989).

Phenotypic characterization. Biochemical characterization of the isolates was performed using API 20E and API ZYM test strips (bioMérieux) and metabolic fingerprinting was carried out by means of Biolog GN2 microtitre plates. Preparations were done according to the manufacturers' instructions, with slight modifications (Thompson et al., 2002b). Classical bacteriological tests were performed as described previously (Baumann et al., 1984; Farmer \& Hickman-Brenner, 1992; Thompson et al., 2002b; Vandamme et al., 1998). Antibiograms were carried out using the disc-diffusion method (Acar \& Goldstein, 1996) with commercial discs (Oxoid). The inhibition zone of each antibiotic was measured for strains grown on Iso-sensitest agar (Oxoid) supplemented with $1.5 \%(w / v)$ $\mathrm{NaCl}$ for $24 \mathrm{~h}$ at $28{ }^{\circ} \mathrm{C}$. Fatty acid methyl ester (FAME) analysis was carried out as described by Huys et al. (1994). Isolates were grown on trypticase soy broth (Becton Dickinson) supplemented with

Table 1. Strains included in this study

Abbreviations: LMG, BCCM/LMG Bacteria Collection, Ghent, Belgium; LCMM, Laboratory for Culture of Marine Molluscs, Florianópolis, Brazil; CENAIM, Center for Marine and Aquaculture Research, Guayaquil, Ecuador; ARC, Artemia Reference Center, Ghent, Belgium; CAIM, Collection of Aquacultural Important Micro-organisms, Mazatlán, Mexico.

\begin{tabular}{|c|c|c|}
\hline $\operatorname{Strain}(s)$ & $\begin{array}{l}\text { Location and date } \\
\text { of isolation }\end{array}$ & Source \\
\hline \multicolumn{3}{|l|}{ Vibrio neptunius sp. nov. (FAFLP group A5) } \\
\hline LMG $20536^{\mathrm{T}}\left(=\right.$ CAIM $\left.532^{\mathrm{T}}=\mathrm{INCO} 17^{\mathrm{T}}\right)$ & LCMM, 1998 & Bivalve larvae (Nodipecten nodosus) \\
\hline LMG 20610 & ARC, 1999 & Culture water of rotifers \\
\hline LMG 20611, R-15119, R-15120, R-15121 & ARC, 1999 & Rotifer in recirculation system (Brachionus plicatilis) \\
\hline LMG 20612 & ARC, 1996 & Gut of turbot larvae (Scophthalmus maximus) \\
\hline LMG 20613, R-15113, R-15116, R-15117 & ARC, 1999 & Rotifer in recirculation system (B. plicatilis) \\
\hline LMG 20614, R- 15118, R-15108, R-15111, R-15112 & ARC, 1999 & Rotifer in recirculation system (B. plicatilis) \\
\hline LMG 20615 & LCCM, 1998 & Diseased bivalve larvae (N. nodosus) \\
\hline R-1575, R-1579, R-1592 & ARC, 1997 & Gut of turbot larvae (S. maximus) \\
\hline R-15123 & ARC, 1999 & Healthy rotifer (B. plicatilis) \\
\hline \multicolumn{3}{|l|}{ Vibrio brasiliensis sp. nov. (FAFLP group A8) } \\
\hline $\begin{array}{c}\text { LMG } 20546^{\mathrm{T}}\left(=\text { CAIM } 495^{\mathrm{T}}=\text { INCO } 317^{\mathrm{T}}\right), \text { LMG } 20010 \\
\quad(=\mathrm{INCO} 320), \mathrm{R}-15002, \mathrm{R}-15003, \mathrm{R}-15004, \mathrm{R}-15005\end{array}$ & LCMM, 1999 & Bivalve larvae (N. nodosus) \\
\hline \multicolumn{3}{|l|}{ Vibrio xuii sp. nov. (FAFLP group A23) } \\
\hline LMG $21346^{\mathrm{T}}\left(=\right.$ CAIM $\left.467^{\mathrm{T}}=\mathrm{STD} 3-1071^{\mathrm{T}}\right)$ & Dahua (China), 1995 & Shrimp culture water \\
\hline LMG 21347 (=CAIM 568 =STD3-1204) & CENAIM, 1995 & White shrimp (Litopenaeus vannamei) \\
\hline LMG 20011 (=INCO 167) & LCMM, 1998 & Bivalve larvae (N. nodosus) \\
\hline
\end{tabular}


$1.5 \%(\mathrm{w} / \mathrm{v})$ Bacto agar (Becton Dickinson) and $1.5 \%(\mathrm{w} / \mathrm{v}) \mathrm{NaCl}$ at $28{ }^{\circ} \mathrm{C}$ for $24 \mathrm{~h}$. Approximately $50 \mathrm{mg}$ cells was harvested and the fatty acids were isolated following the recommendations of the manufacturer using the Microbial Identification System manual and software, version 3.9 (Microbial ID).

\section{RESULTS AND DISCUSSION}

The 30 Vibrio isolates formed three groups by FAFLP fingerprinting analysis. FAFLP groups A5, A8 and A23 had complex band patterns, respectively consisting of $126 \pm 14$, $115 \pm 7$ and $83 \pm 14$ bands (50-536 bp) (Fig. 1). The three FAFLP groups were clearly different from known Vibrio species (Thompson et al., 2001), suggesting that they represent novel species. Isolates of group A5 shared at least $75 \%$ pairwise pattern similarity and showed less than $71 \%$ pairwise pattern similarity towards other Vibrio species. Surprisingly, these strains, which were isolated over a 4-year period and from different places, showed remarkable genome resemblance. For instance, strains LMG $20536^{\mathrm{T}}$, isolated in 1998 at Florianópolis island (Brazil), and LMG 20612, isolated in 1996 at the ARC (Belgium), had $87.5 \%$ pattern similarity. Some strains, e.g. pairs LMG 20614 and R-15108 and R-15111 and R-15112, clustered at the reproducibility level of FAFLP (i.e. $\geqslant 88 \%$ pattern similarity) and were thus indistinguishable by FAFLP. Isolates of FAFLP groups A8 and A23 respectively showed mutual similarities of at least 82 and $62 \%$ and similarity levels below 73 and $54 \%$ towards other Vibrio species.
The value of AFLP in determining genome divergence and species delineation for other bacterial genera, e.g. Agrobacterium and Xanthomonas, has also been appreciated (Mougel et al., 2002; Rademaker et al., 2000). Mougel et al. (2002) calculated that strains belonging to the same species of Agrobacterium would have about $86 \%$ FAFLP band pattern similarity, while Rademaker et al. (2000) found about $65 \%$ AFLP pattern similarity between strains of the same species.

The 16S rDNA sequences of two representative isolates of each FAFLP group were determined and were allocated to the genus Vibrio by the FASTA program. Isolates LMG $20536^{\mathrm{T}}$ (EMBL accession no. AJ316171; $1468 \mathrm{bp}$ ) and LMG 20613 (AJ490150, $681 \mathrm{bp}$ ) had 99.9\% 16S rDNA similarity, whereas LMG 20546 ${ }^{\mathrm{T}}$ (AJ316172; $1504 \mathrm{bp}$ ) and LMG 20010 (AJ490151, $467 \mathrm{bp}$ ) had $99 \cdot 3 \%$ similarity. Strains LMG $21346^{\mathrm{T}}$ (AJ316181; $\left.1435 \mathrm{bp}\right)$ and LMG 21347 (AJ490152, 1123 bp) had $99 \cdot 2 \%$ similarity. Clustering obtained by the neighbour-joining, maximum-likelihood and maximum-parsimony methods was in agreement and the closest phylogenetic neighbours of the three novel Vibrio species were Vibrio tubiashii (98-98.8\%), Vibrio nereis (97.6-98.8\%), Vibrio coralliilyticus $(96 \cdot 8-98 \cdot 5 \%)$, Vibrio mytili $(96 \cdot 8-98 \cdot 2 \%)$ and Vibrio diabolicus $(97 \cdot 1-98 \cdot 1 \%)$ (Fig. 2). V. coralliilyticus and LMG $20536^{\mathrm{T}}$ were closely related, having $98 \cdot 2 \% 16 \mathrm{~S}$ rDNA similarity, and so were LMG $20546^{\mathrm{T}}$ and LMG $21346^{\mathrm{T}}(98 \cdot 4 \%)$. Strain LMG $20536^{\mathrm{T}}$ had $97 \cdot 2 \% 16 \mathrm{~S}$ rDNA similarity towards strains

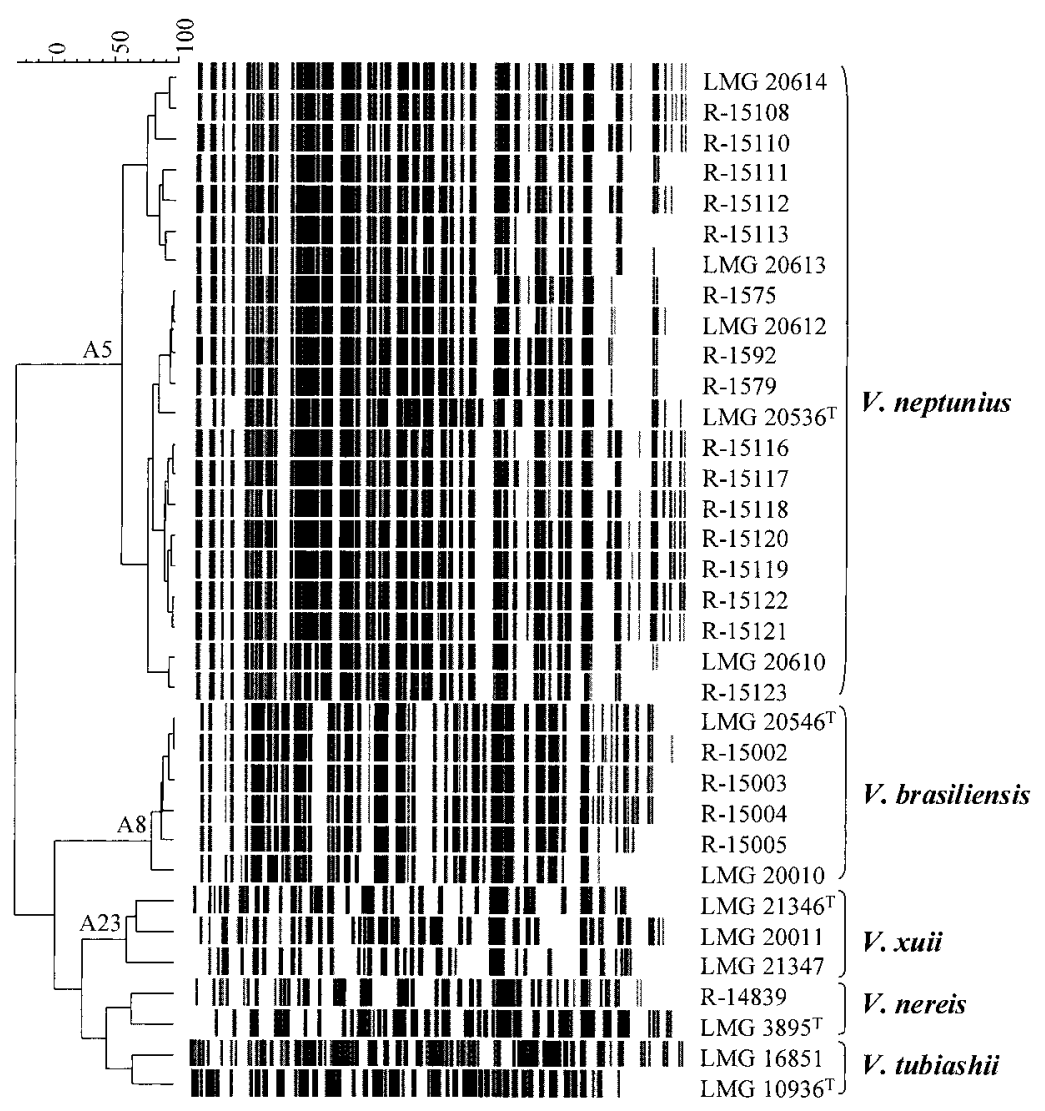

Fig. 1. Dendrogram of FAFLP patterns of 30 marine aquaculture Vibrio isolates. $V$. tubiashii and $V$. nereis were included as outgroups. A band-based (Dice) cluster analysis (Ward) was used. 


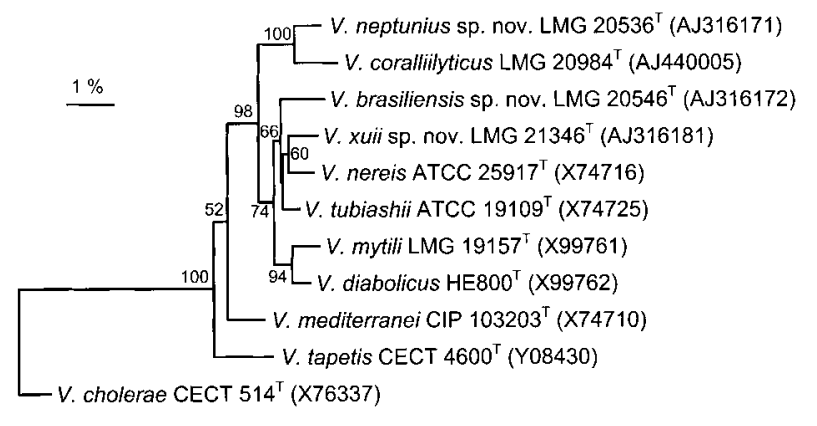

Fig. 2. Phylogenetic tree with the estimated positions of Vibrio neptunius sp. nov., Vibrio brasiliensis sp. nov. and Vibrio xuii sp. nov., using the neighbour-joining method based on the almost complete 16S rDNA sequences. Bootstrap analyses were made with 1000 cycles; values greater than $50 \%$ are indicated on the branching nodes. Bar, $1 \%$ estimated sequence divergence.

LMG $20546^{\mathrm{T}}$ and LMG $21346^{\mathrm{T}}$. Similarity levels of the three proposed novel species towards other genera of the family Vibrionaceae were below $95 \%$.

Two representative isolates of each FAFLP group were chosen for DNA-DNA hybridization experiments. The levels of DNA relatedness within each FAFLP group were $\geqslant 93 \%$, but less than $67 \%$ towards other phylogenetic related Vibrio species (Table 2). DNA-DNA hybridizations confirmed the FAFLP grouping and also revealed other interesting relationships. For instance, FAFLP group A5 was found to be highly related (64-66\%) to the recently described coral-pathogenic species V.coralliilyticus (Ben-Haim et al., 2003); V. coralliilyticus belongs to FAFLP clusters A1-A3 (Thompson et al., 2001).
The 30 Vibrio isolates examined in this study had the main phenotypic and chemotaxonomic features of the genus Vibrio (Bertone et al., 1996; Farmer \& Hickman-Brenner, 1992; Lambert et al., 1983). They were slightly curved rods, Gram-negative, oxidase- and catalase-positive and motile by means of at least one polar flagellum. The major fatty acids were summed feature 3 (comprising $16: 1 \omega 7 c$ and/or $15: 0$ iso $2-\mathrm{OH}), 16: 0,18: 1 \omega 7 c$ and $14: 0$, accounting for $\geqslant 68 \%$ of the total fatty acids (Table 3 ). These facultatively anaerobic isolates grew on thiosulphate/citrate/bile salts/ sucrose (TCBS) agar, forming yellow colonies, but they did not grow without $\mathrm{NaCl}$ or in presence of the vibriostatic agent $\mathrm{O} / 129$ at 10 or $150 \mu \mathrm{g}$ per disc (except LMG $21346^{\mathrm{T}}$ ). Prolific growth occurred in media containing $2.5 \%(\mathrm{w} / \mathrm{v})$ $\mathrm{NaCl}$ at $28{ }^{\circ} \mathrm{C}$. None of the isolates fermented inositol, sorbitol, rhamnose or melibiose. All isolates utilized dextrin, $N$-acetyl-D-glucosamine, D-fructose, $\alpha$-D-glucose, maltose, D-mannose, psicose, D-trehalose, DL-lactic acid, succinic acid, L-alanine, L-alanyl glycine, L-asparagine, L-aspartic acid, L-glutamic acid, glycyl L-aspartic acid, L-serine, inosine, uridine and thymidine as sole carbon sources. None of the isolates utilized adonitol, D-arabitol, $i$-erythritol, L-fucose, $m$-inositol, $\alpha$-lactose, $\alpha$-D-lactose lactulose, D-melibiose, D-raffinose, L-rhamnose, xylitol, cis-aconitic acid (except LMG $21346^{\mathrm{T}}$ ), citric acid, formic acid, Dgalactonic acid lactone, D-galacturonic acid, D-glucosaminic acid, D-glucuronic acid, $\alpha$-hydroxybutyric acid, itaconic acid, $\alpha$-ketovaleric acid, malonic acid, quinic acid, D-saccharic acid, sebacic acid, succinamic acid, glucuronamide, L-histidine, L-leucine, L-pyroglutamic acid, DLcarnitine, urocanic acid or phenyl ethylamine. None of the isolates was luminescent, but they reduced nitrate and were Voges-Proskauer and methyl red positive. The 30 isolates produced indole, alkaline phosphatase, esterase

Table 2. DNA-DNA similarity and DNA G+C content of marine aquaculture Vibrio isolates and related Vibrio species

\begin{tabular}{|c|c|c|c|c|c|c|c|c|c|c|c|c|c|}
\hline Strain & $\mathrm{G}+\mathrm{C}$ content $(\mathrm{mol} \%)$ & \multicolumn{12}{|c|}{ DNA-DNA hybridization with DNA from: } \\
\hline 1. V. mediterranei $\mathrm{LMG} 11258^{\mathrm{T}}$ & $43 \cdot 8$ & 100 & & & & & & & & & & & \\
\hline 2. V. mytili LMG $19157^{\mathrm{T}}$ & $44 \cdot 6$ & 21 & 100 & & & & & & & & & & \\
\hline 3. V. diabolicus $\mathrm{LMG} 19805^{\mathrm{T}}$ & $45 \cdot 6$ & 22 & 37 & 100 & & & & & & & & & \\
\hline 4. V. coralliilyticus LMG $20984^{\mathrm{T}}$ & $46 \cdot 2$ & 19 & 22 & 23 & 100 & & & & & & & & \\
\hline \multicolumn{14}{|l|}{ V. neptunius sp. nov. } \\
\hline 7. LMG $20536^{\mathrm{T}}$ & $46 \cdot 0$ & 20 & 25 & 26 & 64 & 34 & 34 & 100 & & & & & \\
\hline 8. LMG 20613 & $45 \cdot 3$ & 24 & 27 & 27 & 66 & 37 & 38 & 93 & 100 & & & & \\
\hline \multicolumn{14}{|l|}{ V. brasiliensis sp. nov. } \\
\hline 9. LMG $20546^{\mathrm{T}}$ & $45 \cdot 9$ & 17 & 20 & 22 & 25 & 32 & 34 & 32 & 29 & 100 & & & \\
\hline 12. LMG 21347 & $47 \cdot 1$ & 16 & 28 & 26 & 24 & 41 & 27 & 29 & 26 & 25 & 26 & 94 & 100 \\
\hline
\end{tabular}

ND, Not done. 
Table 3. Fatty acid compositions of the novel Vibrio species

Values are percentages (means $\pm \mathrm{SD}$ ) of total fatty acids. Only values above $0 \cdot 1 \%$ are included.

\begin{tabular}{|lrrc|}
\hline Fatty acid & $\boldsymbol{V}$. neptunius & $\boldsymbol{V}$. brasiliensis & $\boldsymbol{V} \cdot$ xuii \\
\hline $12: 0$ & $1 \cdot 9 \pm 0 \cdot 3$ & $1 \cdot 4 \pm 0 \cdot 2$ & $3 \cdot 2 \pm 0 \cdot 0$ \\
$14: 0$ & $5 \cdot 5 \pm 0 \cdot 6$ & $4 \cdot 6 \pm 0 \cdot 1$ & $3 \cdot 5 \pm 0 \cdot 3$ \\
$15: 0$ & $1 \cdot 7 \pm 0 \cdot 3$ & $1 \cdot 0 \pm 0 \cdot 1$ & $0 \cdot 9 \pm 0 \cdot 1$ \\
$16: 0$ & $18 \cdot 0 \pm 0 \cdot 8$ & $11 \cdot 3 \pm 0 \cdot 3$ & $12 \cdot 5 \pm 0 \cdot 6$ \\
$17: 0$ & $2 \cdot 3 \pm 0 \cdot 2$ & $0 \cdot 6 \pm 0 \cdot 1$ & $0 \cdot 5 \pm 0 \cdot 1$ \\
$13: 0$ iso & $1 \cdot 0 \pm 0 \cdot 0$ & $1 \cdot 0 \pm 0 \cdot 0$ & - \\
$14: 0$ iso & $0 \cdot 2 \pm 0 \cdot 1$ & $3 \cdot 3 \pm 0 \cdot 4$ & $1 \cdot 2 \pm 0 \cdot 1$ \\
$15: 0$ iso & $1 \cdot 2 \pm 0 \cdot 3$ & $1 \cdot 8 \pm 0 \cdot 1$ & $1 \cdot 1 \pm 0 \cdot 1$ \\
$16: 0$ iso & $0 \cdot 5 \pm 0 \cdot 1$ & $10 \cdot 5 \pm 0 \cdot 6$ & $5 \cdot 5 \pm 0 \cdot 4$ \\
$17: 0$ iso & $1 \cdot 5 \pm 0 \cdot 1$ & $1 \cdot 4 \pm 0 \cdot 1$ & - \\
$18: 0$ iso & - & $1 \cdot 1 \pm 0 \cdot 0$ & - \\
$12: 0$ 3-OH & $2 \cdot 1 \pm 0 \cdot 6$ & $1 \cdot 5 \pm 0 \cdot 3$ & $1 \cdot 4 \pm 0 \cdot 0$ \\
$14: 0$ iso 3-OH & $0 \cdot 1 \pm 0 \cdot 1$ & $1 \cdot 3 \pm 0 \cdot 2$ & $0 \cdot 9 \pm 0 \cdot 1$ \\
$16: 1 \omega 7 c$ alcohol & $0 \cdot 9 \pm 0 \cdot 3$ & $0 \cdot 3 \pm 0 \cdot 0$ & - \\
$17: 1 \omega 6 c$ & $1 \cdot 2 \pm 0 \cdot 1$ & $0 \cdot 3 \pm 0 \cdot 1$ & $0 \cdot 2 \pm 0 \cdot 0$ \\
$17: 1 \omega 8 c$ & $2 \cdot 1 \pm 0 \cdot 1$ & $0 \cdot 7 \pm 0 \cdot 1$ & - \\
$18: 1 \omega 7 c$ & $17 \cdot 8 \pm 1 \cdot 6$ & $17 \cdot 3 \pm 0 \cdot 3$ & $21 \cdot 0 \pm 2 \cdot 4$ \\
$11-$ methyl $18: 1 \omega 7 c$ & $0 \cdot 6 \pm 0 \cdot 3$ & - & - \\
Summed feature $2^{*}$ & $2 \cdot 4 \pm 0 \cdot 3$ & $1 \cdot 8 \pm 0 \cdot 3$ & $2 \cdot 6 \pm 0 \cdot 0$ \\
Summed feature $3 *$ & $35 \cdot 7 \pm 0 \cdot 9$ & $34 \cdot 7 \pm 1 \cdot 0$ & $38 \cdot 7 \pm 1 \cdot 5$ \\
& & & \\
\hline
\end{tabular}

${ }^{*}$ Summed feature 2: one or more of 14:0 3-OH, 16:1 iso I, an unidentified fatty acid with equivalent chain-length of $10 \cdot 928$ and/or 12:0 ALDE. Summed feature 3: $16: 1 \omega 7 c$ and/or $15: 0$ iso 2-OH.

(C4), esterase lipase (C8), lipase (C14), leucine arylamidase and valine arylamidase (except LMG 20613), but they did not produce urease, $\mathrm{H}_{2} \mathrm{~S}$, lysine or ornithine decarboxylases, $\alpha$-chymotrypsin, $\alpha$-galactosidase, $\beta$-glucuronidase, $\beta$-glucosidase or $\alpha$-fucosidase. The 30 isolates were sensitive to chloramphenicol (30 $\mu$ g per disc) (except LMG $21346^{\mathrm{T}}$ ), tetracycline $(30 \mu \mathrm{g}$ per disc) and polymyxin $\mathrm{B}(300 \mathrm{U})$ and resistant to kanamycin (30 $\mu \mathrm{g}$ per disc).

We propose to accommodate the 30 Vibrio isolates examined in the present study in three novel species, Vibrio neptunius sp. nov., Vibrio brasiliensis sp. nov. and Vibrio xuii sp. nov. The three novel Vibrio species can be differentiated from each other and from other Vibrio species by a number of phenotypic features (Table 4). Quantitative and qualitative differences were detected in the fatty acid compositions of these novel species. Of special interest were the fatty acids 14:0 iso, $14: 0$ iso $3-\mathrm{OH}$ and 16:0 iso, which appeared at a higher concentration in group $\mathrm{A} 8$, and the fatty acids $16: 0,17: 0$ and $17: 1 \omega 8 c$, which were present at a higher concentration in group A5.

\section{Description of Vibrio neptunius sp. nov.}

Vibrio neptunius (nep.tu' ni.us. L. masc. adj. neptunius of Neptune, the Roman god of the sea).
Cells are $1 \mu \mathrm{m}$ wide and $2 \cdot 3-3 \mu \mathrm{m}$ long. Forms translucent, convex, non-swarming, smooth-rounded colonies with entire margins, beige in colour and about $3 \mathrm{~mm}$ in diameter on TSA after $48 \mathrm{~h}$ incubation at $28^{\circ} \mathrm{C}$; colonies are yellow, umbonate, round, entire, smooth, shiny and transparent and $2-3 \mathrm{~mm}$ in size on TCBS after $24 \mathrm{~h}$ at $28^{\circ} \mathrm{C}$. No growth in the absence of $\mathrm{NaCl}$ or in the presence of $\geqslant$ $8.0 \%(\mathrm{w} / \mathrm{v}) \mathrm{NaCl}$. No growth at 4 or $\geqslant 40^{\circ} \mathrm{C}$. Strains are facultatively anaerobic and ferment $\mathrm{D}$-glucose and sucrose. None of the strains ferments mannitol or amygdalin. All strains utilize citrate, glycogen, D-mannose, methyl $\beta$-Dglucoside, sucrose, D-serine, L-threonine, glucose 1-phosphate and glucose 6-phosphate as sole carbon sources. None of the strains utilizes Tween 80, N-acetyl-D-galactosamine, L-arabinose, cellobiose, D-galactose, gentiobiose, D-mannitol, D-sorbitol, turanose, monomethyl succinate, D-gluconic acid, $\beta$-hydroxybutyric acid, $\gamma$-hydroxybutyric acid, p-hydroxyphenylacetic acid, hydroxy-L-proline, L-phenylalanine, DL-carnitine, $\gamma$-aminobutyric acid, putrescine or 2 , 3-butanediol as a sole carbon source. Strains produce gelatinase, tryptophan deaminase, trypsin and $N$-acetyl- $\beta$ glucosaminidase, but they do not produce cystine arylamidase, acid phosphatase, naphthol-AS-BI-phosphohydrolase, $\beta$-galactosidase or $\alpha$-glucosidase. Arginine dihydrolase is variable, but positive for the type strain. The major fatty acids are summed feature $3(35 \cdot 7 \pm 0 \cdot 9 \%), 16: 0(18 \cdot 0 \pm$ $0 \cdot 8 \%)$ and $18: 1 \omega 7 c(17 \cdot 8 \pm 1 \cdot 6 \%)$ (Table 3$)$. Strains are resistant to ampicillin ( $25 \mu \mathrm{g}$ per disc). Additional phenotypic features are listed as supplementary material in IJSEM Online (http://ijs.sgmjournals.org/). The type strain of this species is LMG $20536^{\mathrm{T}}\left(=\right.$ CAIM $\left.532^{\mathrm{T}}\right)$, isolated from larvae of the bivalve Nodipecten nodosus in the south of Brazil. The G $+\mathrm{C}$ content of the type strain is $46 \cdot 0 \mathrm{~mol} \%$.

\section{Description of Vibrio brasiliensis sp. nov.}

Vibrio brasiliensis (bra.si.li.en'sis. N.L. masc. adj. brasiliensis from Brazil).

Cells are $1 \mu \mathrm{m}$ wide and $2 \cdot 5-3 \mu \mathrm{m}$ long. Forms translucent, convex, smooth-rounded colonies with entire margins, beige in colour and $2 \cdot 5-3 \mathrm{~mm}$ in size on TSA after $48 \mathrm{~h}$ incubation at $28{ }^{\circ} \mathrm{C}$. Colonies are yellow, umbonate, wavy, shiny, translucent, round with scalloped margins and about $3 \mathrm{~mm}$ in size on TCBS after $24 \mathrm{~h}$ incubation at $28{ }^{\circ} \mathrm{C}$. No growth in the absence of $\mathrm{NaCl}$ or in the presence of $\geqslant 8.0 \% \mathrm{NaCl}$. No growth at 4 or $\geqslant 45^{\circ} \mathrm{C}$. Facultatively anaerobic and ferments D-glucose, sucrose, mannitol and amygdalin. None of the strains ferments arabinose. All strains utilize $\alpha$-cyclodextrin, glycogen, cellobiose, gentiobiose, D-galactose, gentiobiose, $\alpha$-D-glucose, D-mannitol, methyl $\beta$-D-glucoside, sucrose, methyl pyruvate, $\beta$-hydroxybutyric acid, bromosuccinic acid, L-glutamic acid, glycyl L-aspartic acid, glycyl L-glutamic acid, L-ornithine, L-proline, D-serine, L-threonine and glycerol as sole carbon sources. None of the strains utilizes $\mathrm{N}$-acetyl-D-galactosamine, adonitol, $\gamma$-hydroxybutyric acid, $p$-hydroxyphenylacetic acid, $\alpha$-ketoglutaric acid, $\alpha$-ketovaleric acid, alaninamide, L-phenylalanine, 2-aminoethanol, 2,3-butanediol, 
Table 4. Features useful in differentiating V. neptunius, V. brasiliensis and V. xuii spp. nov. from closely related Vibrio species

Species are identified as: $1, V$. neptunius sp. nov. $(n=21) ; 2, V$. brasiliensis sp. nov. $(n=6) ; 3$. V. xuii sp. nov. ( $n=3)$; 4, Vibrio aestuarianus; 5, Vibrio anguillarum; 6, Vibrio cyclitrophicus; 7, V. coralliilyticus; 8, V. diabolicus; 9, Vibrio diazotrophicus; 10, Vibrio fluvialis; 11, Vibrio lentus; 12, V. mediterranei; 13, V. mytili; 14, V. nereis; 15, Vibrio splendidus; 16, V. tubiashii. Phenotypic data for reference species were obtained from Ben-Haim et al. (2003); Baumann et al. (1984); Farmer \& Hickman-Brenner (1992); Hedlund \& Staley (2001); Macián et al. (2001); Pujalte et al. (1993) and Raguénès et al. (1997). Fatty acid profiles of known Vibrio species (type strains) are from our own database. ND, No data; $v$, variable.

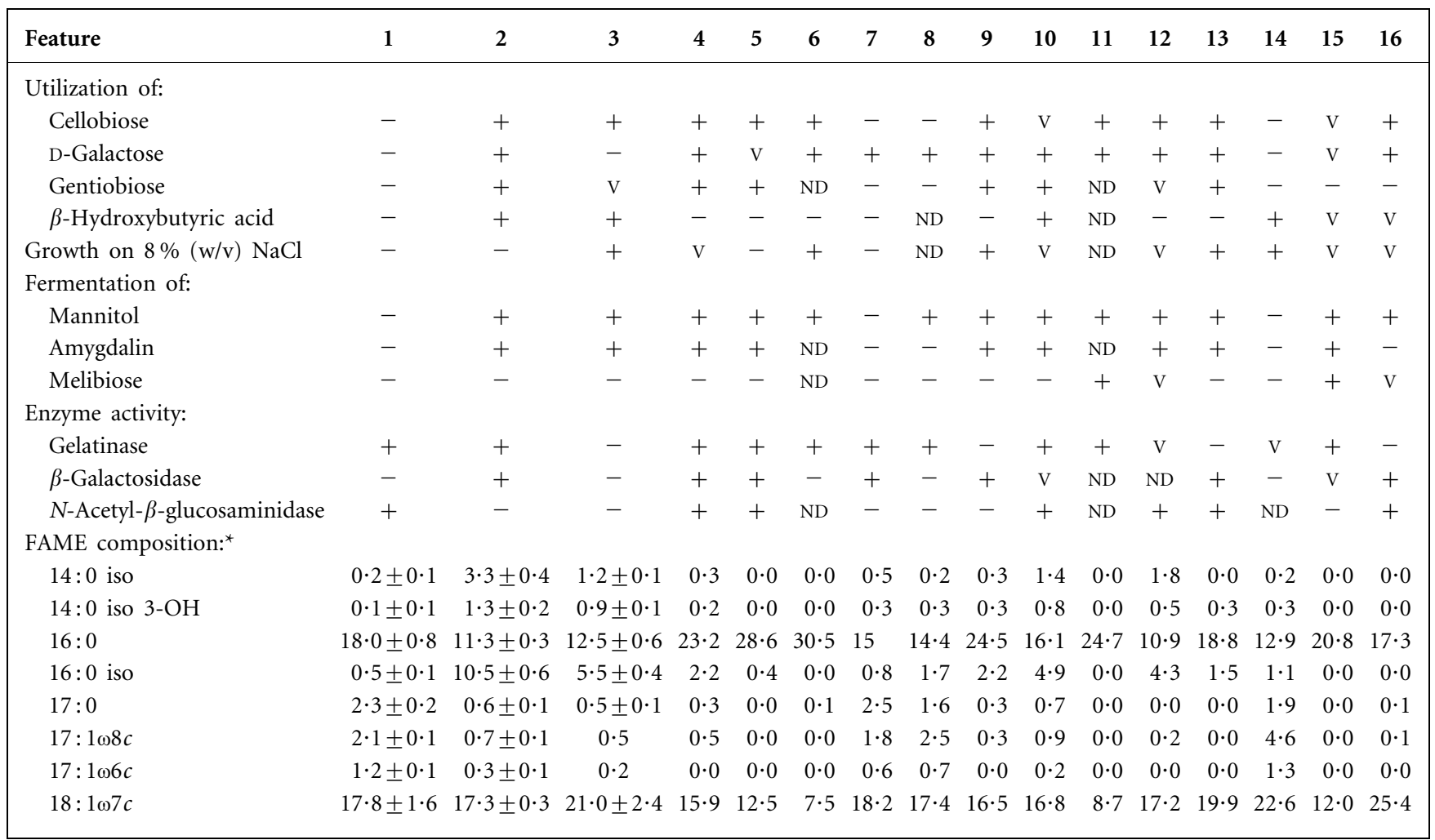

${ }^{\star}$ Means \pm SD as percentages of total fatty acids.

DL- $\alpha$-glycerol phosphate, glucose 1-phosphate or glucose 6-phosphate as a sole carbon source. All strains produce arginine dihydrolase, $\beta$-galactosidase and gelatinase. None of the strains produces trypsin, acid phosphatase, $\alpha$-glucosidase or $N$-acetyl- $\beta$-glucosaminidase. The most abundant fatty acids are summed feature $3(34 \cdot 7 \pm 1 \cdot 0 \%)$, $18: 1 \omega 7 c(17 \cdot 3 \pm 0 \cdot 3 \%), 16: 0(11 \cdot 3 \pm 0 \cdot 3 \%)$ and $16: 0$ iso $(10 \cdot 5 \pm 0 \cdot 6 \%)$ (Table 3$)$. Additional phenotypic features are listed online in the supplementary material. Isolated from larvae of the bivalve $N$. nodosus in the south of Brazil. The type strain is strain LMG $20546^{\mathrm{T}}$ $\left(=\mathrm{CAIM} 495^{\mathrm{T}}\right)$. The $\mathrm{G}+\mathrm{C}$ content of the type strain is $45 \cdot 9 \mathrm{~mol} \%$.

\section{Description of Vibrio xuii sp. nov.}

Vibrio xuii (xu'i.i. N.L. gen. n. xuii of Xu, in honour of the microbiologist $\mathrm{H}$. Xu).

Cells are $1 \mu \mathrm{m}$ wide and $2-3 \mu \mathrm{m}$ long. Forms translucent, convex, smooth-rounded colonies with entire margins, beige in colour and $3-4 \mathrm{~mm}$ in size on TSA after $48 \mathrm{~h}$ incubation at $28{ }^{\circ} \mathrm{C}$. Colonies are yellow, convex, round, entire, shiny, translucent and about $2 \mathrm{~mm}$ in size on TCBS after $24 \mathrm{~h}$ incubation at $28^{\circ} \mathrm{C}$. No growth in the absence of $\mathrm{NaCl}$ or in the presence of $\geqslant 10.0 \% \mathrm{NaCl}$. No growth at 4 or $\geqslant 45{ }^{\circ} \mathrm{C}$. Facultatively anaerobic organism that ferments glucose, mannitol, sucrose, amygdalin and arabinose. Utilizes $\alpha$-cyclodextrin, Tweens 40 and $80, \mathrm{~N}$ acetyl-D-galactosamine, L-arabinose, cellobiose, D-mannitol, D-mannose, D-sorbitol, sucrose, methyl pyruvate, monomethyl succinate, acetic acid, D-gluconic acid, $\beta$-hydroxybutyric acid, $\gamma$-hydroxybutyric acid, $p$-hydroxyphenylacetic acid, $\alpha$-ketoglutaric acid, D-alanine, glycyl L-glutamic acid, L-proline, L-threonine, 2,3-butanediol, glycerol and DL- $\alpha$-glycerol phosphate as sole carbon sources. Does not utilize D-galactose, gentiobiose, methyl $\beta$-Dglucoside, D-raffinose, $\alpha$-ketobutyric acid, propionic acid, D-serine, quinic acid, sebacic acid, hydroxy-L-proline, 2aminoethanol or glucose 1-phosphate as a sole carbon source. Produces arginine dihydrolase, acid phosphatase, naphthol-AS-BI-phosphohydrolase and tryptophan deaminase. Does not produce cystine arylamidase, trypsin, 
$\beta$-galactosidase, $\alpha$-glucosidase, $N$-acetyl- $\beta$-glucosaminidase or gelatinase. The major fatty acids are summed feature $3(38 \cdot 7 \pm 1 \cdot 5 \%), \quad 18: 1 \omega 7 c(21 \cdot 0 \pm 2 \cdot 4 \%)$ and $16: 0$ $(12 \cdot 5 \pm 0 \cdot 6 \%)$ (Table 3$)$. Sensitive to ampicillin (25 $\mu \mathrm{g}$ per disc). Additional phenotypic features are listed online in the supplementary material. The type strain, LMG $21346^{\mathrm{T}}$ ( = CAIM $467^{\mathrm{T}}$ ), was isolated from shrimp culture water in China. The $\mathrm{G}+\mathrm{C}$ content of the type strain is $46 \cdot 6 \mathrm{~mol} \%$.

\section{ACKNOWLEDGEMENTS}

F. L. T. has a PhD scholarship (no. 2008361/98-6) from Conselho Nacional de Desenvolvimento Científico e Tecnológico (CNPq), Brazil. J. S. acknowledges grants from the Fund for Scientific Research (FWO), Belgium. G. S. R., A. P. and M. M. B. acknowledge support of the EU project INCO Scallop (no. ERBIC 18 CT 970188). The authors are indebted to J. Goris, A. Balcaen and L. Lebbe for their skilful assistance during the DNA-DNA hybridizations and $\mathrm{G}+\mathrm{C}$ measurements. The excellent remarks of two anonymous reviewers are gratefully acknowledged.

\section{REFERENCES}

Acar, J. F. \& Goldstein, F. W. (1996). Disc susceptibility test. In Antibiotics in Laboratory Medicine, 4th edn, pp. 1-51. Edited by V. Lorian. Baltimore: Williams \& Wilkins.

Baumann, P., Furniss, A. L. \& Lee, J. V. (1984). Genus I. Vibrio Pacini 1854. In Bergey's Manual of Systematic Bacteriology, vol. 1, pp. 518-538. Edited by N. R. Krieg \& J. G. Holt. Baltimore: Williams \& Wilkins.

Ben-Haim, Y., Thompson, F. L., Thompson, C. C., Cnockaert, M. C., Hoste, B., Swings, J. \& Rosenberg, E. (2003). Vibrio coralliilyticus sp. nov., a temperature-dependent pathogen of the coral Pocillopora damicornis. Int J Syst Evol Microbiol 53, 309-315.

Bertone, S., Giacomini, M., Ruggiero, C., Piccarolo, C. \& Calegari, L. (1996). Automated systems for identification of heterotrophic marine bacteria on the basis of their fatty acid composition. Appl Environ Microbiol 62, 2122-2132.

Eilers, H., Pernthaler, J. \& Amann, R. (2000). Succession of pelagic marine bacteria during enrichment: a close look at cultivationinduced shifts. Appl Environ Microbiol 66, 4634-4640.

Farmer, J. J., III \& Hickman-Brenner, F. W. (1992). The genera Vibrio and Photobacterium. In The Prokaryotes. A Handbook on the Biology of Bacteria: Ecophysiology, Isolation, Identification, and Applications, 2nd edn, pp. 2952-3011. Edited by A. Balows, H. G. Trüper, M. Dworkin, W. Harder \& K. H. Schleifer. New York: Springer-Verlag.

Gomez-Gil, B., Tron-Mayén, L., Roque, A., Turnbull, J. F., Inglis, V. \& Guerra-Flores, A. L. (1998). Species of Vibrio isolated from hepatopancreas, haemolymph and digestive tract of a population of healthy juvenile Penaeus vannamei. Aquaculture 163, 1-9.

Hansen, G. H. \& Olafsen, J. A. (1999). Bacterial interactions in early life stages of marine cold water fish. Microb Ecol 38, 1-26.

Hedlund, B. P. \& Staley, J. T. (2001). Vibrio cyclotrophicus sp. nov., a polycyclic aromatic hydrocarbon (PAH)-degrading marine bacterium. Int J Syst Evol Microbiol 51, 61-66.

Huys, G., Vancanneyt, M., Coopman, R., Janssen, P., Falsen, E., Altwegg, M. \& Kersters, K. (1994). Cellular fatty acid composition as a chemotaxonomic marker for the differentiation of phenospecies and hybridization groups in the genus Aeromonas. Int J Syst Bacteriol 44, 651-658.

Jukes, T. H. \& Cantor, C. R. (1969). Evolution of protein molecules. In Mammalian Protein Metabolism, pp. 21-132. Edited by H. N. Munro. New York: Academic Press.

Lambert, M. A., Hickman-Brenner, F. W., Farmer, J. J., III \& Moss, C. W. (1983). Differentiation of Vibrionaceae species by their cellular fatty acid composition. Int J Syst Bacteriol 33, 777-792.

Macián, M. C., Ludwig, W., Aznar, R., Grimont, P. A. D., Schleifer, K. H., Garay, E. \& Pujalte, M. J. (2001). Vibrio lentus sp. nov., isolated from Mediterranean oysters. Int J Syst Evol Microbiol 51, 1449-1456.

Mesbah, M., Premachandran, U. \& Whitman, W. B. (1989). Precise measurement of the $\mathrm{G}+\mathrm{C}$ content of deoxyribonucleic acid by high-performance liquid chromatography. Int J Syst Bacteriol 39, 159-167.

Mougel, C., Thioulouse, J., Perrière, G. \& Nesme, X. (2002). A mathematical method for determining genome divergence and species delineation using AFLP. Int $J$ Syst Evol Microbiol 52, 573-586.

Murray, R. G. E., Doetsch, R. N. \& Robinow, C. F. (1994). Determinative and cytological light microscopy. In Methods for General and Molecular Bacteriology, pp. 21-41. Edited by P. Gerhardt. Washington, DC: American Society for Microbiology.

Pitcher, D. G., Saunders, N. A. \& Owen, R. J. (1989). Rapid extraction of bacterial genomic DNA with guanidium thiocyanate. Lett Appl Microbiol 8, 151-156.

Pujalte, M.-J., Ortigosa, M., Urdaci, M.-C., Garay, E. \& Grimont, P. A. D. (1993). Vibrio mytili sp. nov., from mussels. Int J Syst Bacteriol 43, 358-362.

Rademaker, J. L. W., Hoste, B., Louws, F. J., Kersters, K., Swings, J., Vauterin, L., Vauterin, P. \& de Bruijn, F. J. (2000). Comparison of AFLP and rep-PCR genomic fingerprinting with DNA-DNA homology studies: Xanthomonas as a model system. Int J Syst Evol Microbiol 50, 665-677.

Raguénès, G., Christen, R., Guezennec, J., Pignet, P. \& Barbier, G. (1997). Vibrio diabolicus sp. nov., a new polysaccharide-secreting organism isolated from a deep-sea hydrothermal vent polychaete annelid, Alvinella pompejana. Int J Syst Bacteriol 47, 989-995.

Riquelme, C. E., Jorquera, M. A., Rojas, A. I., Avendaño, R. E. \& Reyes, N. (2001). Addition of inhibitor-producing bacteria to mass cultures of Argopecten purpuratus larvae (Lamarck, 1819). Aquaculture 192, 111-119.

Saitou, N. \& Nei, M. (1987). The neighbor-joining method: a new method for reconstructing phylogenetic trees. Mol Biol Evol 4, 406-425.

Sherr, E. \& Sherr, B. (2000). Marine microbes: an overview. In Microbial Ecology of the Oceans, pp. 13-46. Edited by D. L. Kirchman. New York: Wiley-Liss.

Suantika, G., Dhert, P., Rombaut, G., Vandenberghe, J., De Wolf, T. \& Sorgeloos, P. (2001). The use of ozone in a high density recirculation system for rotifers. Aquaculture 201, 35-49.

Thompson, F. L., Hoste, B., Vandemeulebroecke, K. \& Swings, J. (2001). Genomic diversity amongst Vibrio isolates from different sources determined by fluorescent amplified fragment length polymorphism. Syst Appl Microbiol 24, 520-538.

Thompson, F. L., Abreu, P. C. \& Wasielesky, W. (2002a). Importance of biofilm for water quality and nourishment in intensive shrimp culture. Aquaculture 203, 263-278.

Thompson, F. L., Hoste, B., Vandemeulebroecke, K., Engelbeen, K., Denys, R. \& Swings, J. (2002b). Vibrio trachuri Iwamoto et al. 1995 
is a junior synonym of Vibrio harveyi (Johnson and Shunk 1936) Baumann et al. 1981. Int J Syst Evol Microbiol 52, 973-976.

Vandamme, P., Segers, P., Ryll, M. \& 8 other authors (1998). Pelistega europaea gen. nov., sp. nov., a bacterium associated with respiratory disease in pigeons: taxonomic structure and phylogenetic allocation. Int J Syst Bacteriol 48, 431-440.
Verschuere, L., Rombaut, G., Sorgeloos, P. \& Verstraete, W. (2000). Probiotic bacteria as biological control agents in aquaculture. Microbiol Mol Biol Rev 64, 655-671.

Willems, A., Doignon-Bourcier, F., Goris, J., Coopman, R., de Lajudie, P., De Vos, P. \& Gillis, M. (2001). DNA-DNA hybridization study of Bradyrhizobium strains. Int J Syst Evol Microbiol 51, 1315-1322. 